\title{
PTEROSTILBENE ENRICHMENT OF DRY CONVENIENCE FOOD FOR INSTANT MUFFINS*
}

\author{
A. KOGAN, Y. POLYVANOV*, I. HONCHARENKO, E. SUPRUNENKO
}

\author{
Department of Food Technologies, Oles Honchar Dnipro National University, Dnipro, UKRAINE \\ e-mail:mr.egor.pv@gmail.com
}

\begin{abstract}
Modern society is overloaded with uncontrolled flows of information, emotions and stress. On top of that, despite promoting a healthy diet, the populations of many countries are overweight, obese, and having type 2 diabetes. The role of genes in the development of diabetes, obesity and senile dementia is not so great. Vast majority of people obtain eating habits that appear to be significant factors in the onset of syndromes of demetia. Flour confectionery products, which include muffins, have gained popularity in many countries in the world, according to this, the development of technologies related to the enrichment of classical formulations with useful substances or components has relevance and necessity. This is also due to the expansion of the market for flour confectionery products that meet the strategy of a balanced and healthy diet. The aim of the article is to develop recipes and technology for instant muffins from dry semi-processed goods with the addition of dry blueberry powder as a source of pterostilbene, a substance that reduces the risk of early aging, Alzheimer's disease, type 2 diabetes, the effects of stress and depression. The proposed technology ensures the preservation of the beneficial effect of the biologically active substance that undergone heat treatment, due to the afore proposed short-term effect of the prepared mixture when exposed to microwaves. Developed dry mixes for muffins can be recommended for everyone, because they do not contain fat and sugar. Sweetness to the finished product is provided with the extract from stevia leaves. Muffins do not contain chemical disintegrants.
\end{abstract}

Key words: flour products; muffin; pterostelbene; blueberry powder; dementia; early aging; type 2 diabetes

\section{ЗБАГАЧЕННЯ ПТЕРОСТІЛЬБЕНОМ СУХОГО НАПІВФАБРИКАТУ ДЛЯ МАФІНІВ ШВИДКОГО ПРИГОТУВАННЯ*}

\author{
А. Б. КОГАН, С.А. ПОЛИВАНОВ, І. П. ГОНЧАРЕНКО, К. С СУПРУНЕНКО
}

кафедра харчових технологій Дніпровский начіональный університет імені Олеся Гончара, Дніпро, УКРАЇНА

\begin{abstract}
АНОтАЦІ Сучасне суспільство перевантажене неконтрольованими потоками інформачії, емочіями, стресами. На додаток до всього, незважаючи на пропаганду здорового харчування, населення багатьох країн страждає надмірною вагою, ожирінням і діабетом 2 типу. Роль генів в розвитку діабету, ожиріння і старечого недоумства не так вже й відчутна. У переважної більшості людей, значними факторами виникнення синдромів демениії є харчові звички. Борошняні кондитерські вироби, до яких належать мафіни, завоювали популярність у багатьох країнах світу, отже розробка технологій, пов'язаних із збагаченням класичних рецептур корисними речовинами або компонентами, має актуальність $i$ необхідність. Це також пов'язано з розширенням ринку борошняних кондитерських виробів, що відповідають стратегії збалансованого і оздоровчого харчування. Метою статті є розробка рецептур і технології мафінів швидкого приготування з сухого напівфабрикату з додаванням сухого порошку лохини, як джерела птеростільбену - речовини, що дозволяє знизити ризик передчасного старіння, хвороби Альцгеймера, діабету 2 типу, наслідки стресу $і$ депресії. Запропонована технологія забезпечує збереження корисної дї біологічно активної речовини після термічної обробки, оскільки запропоновано короткочасний вплив підготовленої суміші в полі надвисоких частот. Розроблені сухі суміші для мафінів можуть бути рекомендовані для широких верств населення, оскільки не містять жиру і иукру. Солодкість готовому виробу додає екстракт з листя стевії. У складі мафінів не міститься хімічних розпушувачів.
\end{abstract}

Ключові слова: борошняні вироби; мафін; птеростельбен; порошок лохини; деменція; раннє старіння; діабет 2 типу

\section{Introduction}

Most people prefer flour confectionery products for their taste and the feeling of pleasure from eating them. Various types of sugars, fats and complex carbohydrates provide early satiety with one portion of a small volume product. The tasteful harmony of products depends not only on fats and sugars, but also on flavorings and flavoring agents (raisins, nuts, chocolate crisps, coconut flakes, fruit fillings, pralines, etc.).

The presence of such components in flour confectionery products guarantees producers stable conditioned reflexes, taste addiction and a conscious desire of consumers to make a purchase.

\footnotetext{
* Scientific adviser - Head of the Department of Food Technologies, Candidate of Engineering Sciences, Associate Professor, Kondratjuk Nataliia
} 
As you can see, such an addiction arises at the psychological level, i.e. engages the brain. We should not forget about the dangers of an excess of fats and free sugars in the human diet. Therefore, the right balance between taste and benefit for the body is one of the main strategies for the development of the food industry. Proper nutrition is a fundamental factor in a healthy lifestyle. With a constant correlation of these two concepts, the problem of 21 st century is clearly indicated: in the absence of one, the meaning of the other is lost.

The question of the relationship between nutrition and human activity has previously been raised by scientists. To maintain a high level of activity, prophylactic diets were proposed, enrichment of traditional products and rations with components containing biologically active additives, physical education and sports. However, all this was effective only at the time of implementation. With the cessation of physical activity and the use of dietary supplements, disturbances of the body quickly began to accumulate.

It is indisputable fact that poor, unbalanced nutrition leads to a permanent change in DNA [1], depression, chronic headaches and cognitive impairment.

Therefore, the second approach to regulate physical activity (in our opinion) should be to enrich foods and diets with almost no change in taste habits.

Ukraine's food and processing industry's development strategy in the field of confectionery products for the period up to 2020 provides for the enhancement of product quality and competitiveness. Flour confectionery products, including muffins, are the largest sales segment in the Ukrainian confectionery market. They are in high demand in our country's population and are very popular abroad. Mainly domestic ingredients are used in the production of flour confectionery products. That allows you to stay for a long time in the segment of products for the population with low purchasing power.

However, this does not at all make this type of product uninteresting for the solvent population. A variety of tastes, fillings, commodity forms, packaging design, creates all kinds of trajectories for the distribution of flour confectionery among different segments of the population. This is followed by the technical component: the use of resource-saving technologies, new processing methods and innovative concepts of classic products.

It is equally important to expand the assortment to positions that meet the goals and objectives of a balanced and adequate diet to ensure the competitiveness of flour confectionery on the world market. Previously, we developed a dry mix technology to make muffins without sugar and fat. he final stage of product preparation was pouring with water, brew for 5-7 minutes and minute processing in an ultra-high frequency electromagnetic field.

The products have gained popularity among IT employees, financiers, office workers and students, that is, people engaged in mental work. This is precisely what served as an incentive for the development of flour confectionery products (muffins) technologies, with increased content of biologically active substances that regulate brain activity.

Thereby, enrichment of food products, which is in large demand, with substances that restore brain disorders and provide brain activity for a long time, is not just a preventative measure, but a solution to a number of global problems of society.

These conclusions are the result of an analytical study of statistical data, which suggests that in 2018, 50 million people were recorded with the cases of dementia. If timely measures are not taken, then literally in 30 years there will be three times as many people with the cases of dementia [2]. Disappointing prognosis for type 2 diabetes. An increase in the number of patients by 2030 from 420 to 600 million people [3]. Crohn's disease is also considered progressive (2-4 people per 100,000 inhabitants per year) [4].

\section{The aim of the study}

The aim of the work is the expediency of using blueberry powder in the production technology of instant muffins, which allows to expand the range of dishes from semi-finished products of high degree of preparedness, to improve the nutritional value of flour confectionery in prophylaxis purposes.

\section{Statement of the main material}

The insufficient amount of time that a person can spend to a meal is associated with an overall increase in daily activity, lifestyle, which defines the preferred nutrition of high readiness semi-finished products or an increase in snacks. Therefore, in this paper, we consider the development of dry muffins with the addition of dry blueberry powder which contains: pterostilbene and resveratrol, which are derivatives of trans-stilbene. Pterostilbene and resveratrol have a beneficial effect on the cardiovascular system, central nervous system. They have antioxidant, anti-inflammatory properties and inhibit the growth of cancer. In addition, they lower insulin resistance, glucose and cholesterol levels.

The presence of one hydroxyl group in the structure of pterostilbene allows it to easily pass through the blood-brain barrier, which, in addition, is a diffusion barrier essential for the normal functioning of the central nervous system and stays in the body longer than resveratrol [5]. Its advantage, in addition, is that it has the ability to absorb free radicals and protect biomolecules from oxidative effects [6]. According to studies, the use of pterostilbene enhances the effectiveness and reduces the adverse effects of chemoradiotherapy and can enhance immunotherapy. It can be used in combination with conventional cancer treatment methods, thereby increasing their oncostatic effectiveness. Pterostilbene also activates sirtuin - a protein responsible for aging and DNA repair. Pterostilbene has a beneficial effect as antiaging compounds, modulating signs of aging, including 
oxidative damage, inflammation, telomere depletion and cell aging [7].

Resveratrol, according to studies conducted in 2010, affects the secretion and concentration of insulin in the blood. Reduces it with high-calorie diets [8].

Also, resveratrol has antagonistic effects on the development of cancer by regulating microRNAs and short non-coding RNAs [9]. The studies described in the «Journal of Agricultural and Food Chemistry» show that resveratrol has a strong antioxidant and anti-inflammatory effect. [10].

The negative effect of sugar on the human body was taken into account when developing the formulation of instant muffins. With a daily consumption of sugarcontaining foods, cells are exposed to high levels of insulin and gradually reduce the amount of insulin receptors on their surface. Therefore, stevia and fructose replaced sugar. [11-13].

\section{The discussion of the results}

The studies were conducted in the laboratory at the Department of Food Technology of the Oles Honchar Dnipro National University.

Earlier, we developed a formulation of instant muffins with the aroma of "Vanilla", which has a light color of dough. However, during preliminary experiments it was found that the addition of blueberry powder, which was originally dark in color, negatively affects the color of the crumb, so it was decided to use the berry powder in the composition of muffins with cocoa. Blueberry powder in a dosage of flour corresponding to 3,5 and $10 \%$ by weight of flour.

Table 1 - Chocolate muffin recipe with blueberry powder

\begin{tabular}{|c|c|c|c|c|}
\hline \multirow[b]{2}{*}{ Raw materials } & \multicolumn{4}{|c|}{ Raw material consumption per $100 \mathrm{~g}$} \\
\hline & Wheat flour & $\begin{array}{c}\text { Sample № } 1 \\
3 \%\end{array}$ & $\begin{array}{c}\text { Sample № } 2 \\
5 \%\end{array}$ & $\begin{array}{c}\text { Sample № } 3 \\
10 \%\end{array}$ \\
\hline Wheat flour & 20,65 & 20,35 & 20,43 & 20,28 \\
\hline Blueberry powder & - & 0,63 & 1,08 & 2,25 \\
\hline Stevia extract & 0,66 & 0,67 & 0,68 & 0,72 \\
\hline Fructose & 19,71 & 20,04 & 20,53 & 21,52 \\
\hline Egg powder & 12,54 & 12,75 & 13,06 & 13,69 \\
\hline Baking powder & 2,99 & 3,04 & 3,11 & 3,26 \\
\hline Cocoa alkalized & 2,59 & 2,63 & 2,70 & 2,83 \\
\hline Enzyme & 0,40 & 0,40 & 0,41 & 0,43 \\
\hline Vanillin & 0,20 & 0,20 & 0,21 & 0,22 \\
\hline Water & 47,79 & 48,57 & 49,77 & 52,16 \\
\hline Total & 107,53 & 109,29 & 111,98 & 117,37 \\
\hline Output & 100 & 100 & 100 & 100 \\
\hline
\end{tabular}

The technology for preparing the dry mix for instant muffins includes in the following operations:

1. Sifting of dry components;

2. Dosing according to the recipe;

3. Mixing to a homogeneous composition;

4. Filling.

5. Packing.

The following method is used to prepare a chocolate muffin from a semi-finished product:

1. Add a portion of cold water $(20-25 \mathrm{ml})$ to a measured quantity of dry mixture (the weight of one packing unit corresponds to one portion of the finished product);

2. Stir thoroughly for 1-2 minutes;

3. Let it brew for 7-10 minutes (for swelling of the protein-polysaccharide part and activation of enzymes);
4. Bake in the microwave for 1 minute at a power of at least $750 \mathrm{~W}$.

5. Allow to cool before use for 1 minute.

Currently, there are many similar mixtures for making muffins. Muffin mixes are an ideal solution for the general population who want to supplement their diets with mouth-watering and high-quality products, the advantages of which are simplicity and speed of preparation, high organoleptic characteristics and nutritional value. The mixture that we have created can successfully complement the assortment of coffee houses, tea houses, lobby bars and fitness bars. Special equipment is not needed for the preparation of products: whipping machines or food processors, mixers, ovens, high-end stoves, convection ovens. The composition of the base mixture may vary, but the ingredients shown in table one are most often to be used. 
Instant muffins containing pterostilbene can be recommended for the prevention of many diseases, however, during the development of the technology, one problem was identified: the low content of active substance in a dose of blueberry powder, which corresponds to high organoleptic characteristics of readymade muffins (Table 2).

Table 2 - Organoleptic characteristics of muffin with the addition of blueberry powder

\begin{tabular}{|l|l|}
\hline \multicolumn{1}{|c|}{ Indicator } & \multicolumn{1}{c|}{ Characteristics } \\
\hline Appearance & $\begin{array}{l}\text { Inherent to this product, without damage (kinks). With an increase in the dose of blueberry } \\
\text { powder on the surface, the number of cracks and tears increases. }\end{array}$ \\
\hline Color & $\begin{array}{l}\text { Changes in the process of replacing part of the flour with blueberry powder from light } \\
\text { brown to dark brown }\end{array}$ \\
\hline Taste and smell & $\begin{array}{l}\text { Blueberry powder is evenly distributed in the products. With an increase in blueberry } \\
\text { powder, the bakeability of the products will slightly decrease, the acid taste will increase, a } \\
\text { berry aftertaste and smell will appear }\end{array}$ \\
\hline Appearance of fracture & Inherent to the product \\
\hline
\end{tabular}

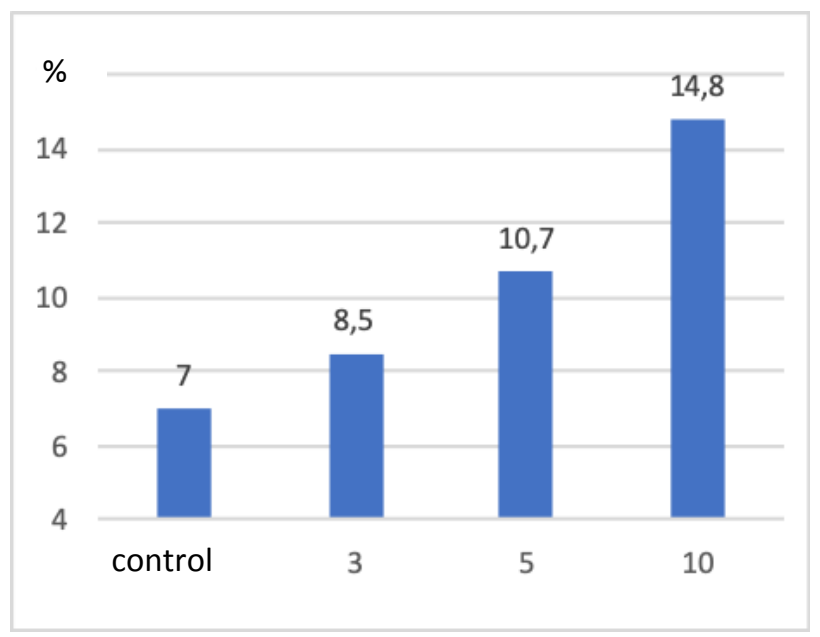

Fig. 1 - Shift in humidity of products depending on the amount of blueberry powder

Fig. 1 shows the results of measuring the moisture content of finished products. With an increase in the dosage of blueberry powder and, consequently, with an increase in organic acids, a decrease in alkalinity was noted. (fig. 2).

Fig. 1 shows that with an increase in berry powder, the moisture of the muffins increases. This is primarily due to the fact that some of the biopolymers (proteins and starchy substances of flour), which have a high waterholding ability, are reduced. The hydrocolloids of blueberry powder are mainly represented by pectin substances, but when taking into account the degree of grinding of the powder to a state of fine dispersion, pectins are present in the form of dilapidated fractions with reduced hydrophilic properties.

Fig. 1 and fig. 2 also show that the humidity and alkalinity values are within the normalized range, however, the organoleptic characteristics of the samples with blueberry powder content indicate that $10 \%$ is the maximum allowable addition of the additional component.

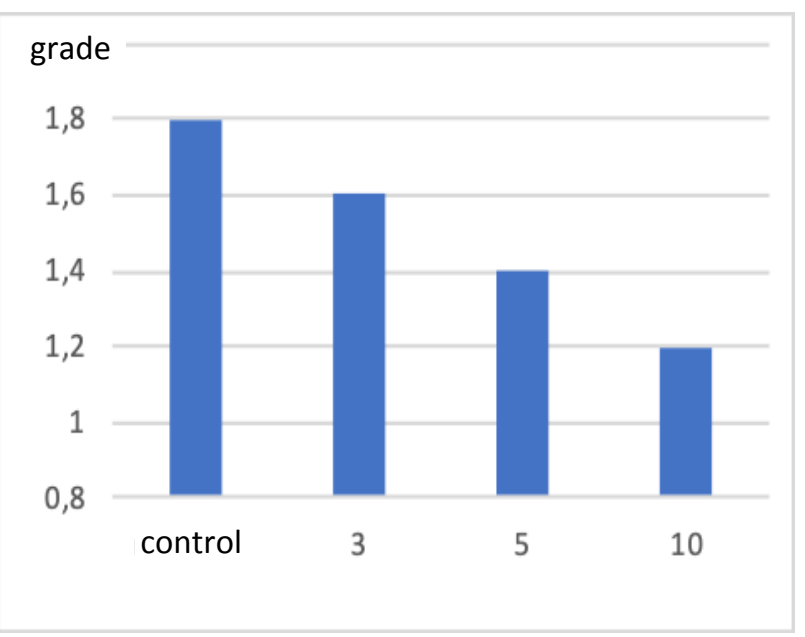

Fig. 2 - Shift in alkalinity of products depending on the amount of blueberry powder.

In this regard, pterostilbene content was measured in the finished product, which was $1 \mu \mathrm{g}$ in 1 portion of the finished muffin. This amount corresponds to only $0.003 \%$ of the recommended norm of $0.5-1.0 . \%$ Of the prophylactic for a number of diseases associated with brain disorders.

Such values are negligible, so we decided to completely replace the cocoa powder with a domestic analogue - crushed flakes made from seeds of dark grapes. This solution allowed us to improve organoleptic characteristics, since the color of the curtain powder is lighter than cocoa. A harmonious dark coloring of the finished product occurred in combination with darkcolored blueberry powder. The cocoa flavor with the substitution turned into an aftertaste, which was enhanced by cocoa extract, as an additional source of chlorhexigenic acids (a substance that reduces weight).

Furthermore, grape seed flakes also contain substances that regulate brain activity and anti-aging processes, respectively resveratrol and hyaluronic acid.

Thus, the obtained samples had not only high organoleptic characteristics, but also a high content of 
substances that support brain activity and reduce the likelihood of early aging of the organism.

\section{Conclusions}

The results of the tasting, organoleptic evaluation and physico-chemical parameters of muffins with blueberry powder and grape shrimp meal indicate that the best results are achieved by replacing $10.0 \%$ premium wheat flour with blueberry powder and completely replacing cocoa powder ( about 3\% by weight of the finished product) for flakes made from grape seed. The obtained samples have good organoleptic and physicochemical characteristics.

The product concept has no analogues in Ukraine and the world and allows us to consider the developed technology as competitive in the domestic and foreign markets, intended for a wide range of people.

This development is not complete. The possibilities of introducing high-readiness pure pterostilbene and resveratrol powders into semi-finished products are currently being considered to obtain more tangible physiological effects.

\section{Список літератури}

1. Kobow, K. Deep sequencing reveals increased DNA methylation in chronic rat epilepsy / K. Kobow, A. Kaspi, K. N. Harikrishnan, K. Kiese, M. Ziemann, I. Khurana, I. Fritzsche, J. Hauke, E. Hahnen, R. Coras, A. Mühlebner, A. El-Osta, I. Blümcke // Acta Neuropathol. 2013. - № 5(126). - P. 741-756. - doi: 10.1007/s00401013-1168-8.

2. Деменция. Всемирная организация здравоохранения. URL: sheets/detail/dementia

3. Диабет. Всемирная организация здравоохранения. URL: https://www.who.int/ru/news-room/factsheets/detail/diabetes.

4. Стяжкина, С. Статистика заболеваемости болезнью крона. Клинический случай течения болезни крона и ее влияние на качество жизни пациента / С. Стяжкина, С. Камалетдинова, М. Н. Махмудова, З. Гимаутдинова // ОЛИМП. - 2016. - № 12(11). - С. 80-82.

5. Kapetanovic, I. M., Pharmacokinetics, oral bioavailability, and metabolic profile of resveratrol and its dimethylether analog, pterostilbene, in rats / I. M. Kapetanovic, M. Muzzio, Z. Huang, T. N. Thompson, D. L. McCormic // Cancer Chemother Pharmacol. - 2011. - № 3(68). - P. 593-601. - doi: 10.1007/s00280-010-1525-4.

6. Acharya, J. D. Protective effect of Pterostilbene against free radical mediated oxidative damage / J. D. Acharya, S. S. Ghaskadbi // BMC Complement Altern Med. - 2013. № 238(13). - P. 1-10. - doi: 10.1186/1472-6882-13-238.

7. Wenzhe, Yu. Pterostilbene inhibited advanced glycation end products (AGEs)-induced oxidative stress and inflammation by regulation of RAGE/MAPK/NF- $\mathrm{KB}$ in RAW264.7 cells / Yu. Wenzhe, Hu. Xiaoqian, Wa. Mingfu // Journal of Functional Foods. - 2018. - (40). - P. 272-279. - doi: 10.1016/j.jff.2017.11.003 .

8. Szkudelska, K. Resveratrol, obesity and diabetes / Szkudelska K., Szkudelski T. // European Journal of Pharmacology. - 2010. - (635). - P. 1-8. - doi: 10.1016/j.ejphar.2010.02.054
9. Wang, M. Non-Coding RNAs as Molecular Targets of Resveratrol Underlying Its Anticancer Effects / M. Wang, S. Jiang, F. Yu, Li Zhou, K. Wang // Journal of Agricultural and Food Chemistry. - 2019. - № 17(67). - P. 4709-4719. - doi: 10.1021/acs.jafc.9b01667.

10. Li, J. A comparative study of anti-aging properties and mechanism: resveratrol and caloric restriction / J. Li, C.-X. Zhang, Y.-M. Liu, K.-L. Chen, G. Chen // Oncotarget. 2017. - № 39(8). - doi: 10.18632/oncotarget.20084.

11. Перлмуттер, Д. Еда и мозг. Что углеводы делают со здоровьем, мышлением и памятью / Д. Перлмуттер, К. Лоберг // Научная литература. Нью-Йорк. - 2013. $460 \mathrm{c}$.

12. Polyvanov, Y. Evaluation of the relevance of the development of food modules with pterostilben and resveratrol of natural origin / Y. Polyvanov, A. Kogan // Dynamics of the development of world science. Abstracts of the 1st International scientific and practical conference. Perfect Publishing. Vancouver, Canada. - 2019. - 248-250.

13. Polyvanov, Y. Berry powders with a high content of pterostilbene and resveratrol in the technology of chocolate flour confectionery / Y. Polyvanov, A. Kogan // Scientific discoveries: projects, strategies and development:

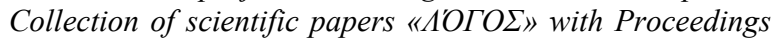
of the International Scientific and Practical Conference. Edinburgh. - 2019. - (1). - 68-70.

\section{References(transliterated)}

1. Kobow, K., Kaspi, A., Harikrishnan, K. N., Kiese, K., Ziemann, M., Khurana, I., Fritzsche, I., Hauke, J., Hahnen, E., Coras, R., Mühlebner, A., El-Osta, A., Blümcke I. Deep sequencing reveals increased DNA methylation in chronic rat. Acta Neuropathol, 2013, 5(126), 741-756, doi: 10.1007/s00401-013-1168-8.

2. Dementsiya. Vsemirnaya organizatsiya zdravookhraneniya. Available at: https://www.who.int/ru/news-room/factsheets/detail/dementia.

3. Diabet. Vsemirnaya organizatsiya zdravookhraneniya. Available at: https://www.who.int/ru/news-room/factsheets/detail/diabetes.

4. Styazhkina, S., Kamaletdinova, S., Makhmudova, M. N., Gimautdinova, Z. Statistika zabolevayemosti bolezn'yu krona. Klinicheskiy sluchay techeniya bolezni krona i yeye vliyaniye na kachestvo zhizni patsiyenta. OLIMP, 2016, 12(11), 80-82.

5. Kapetanovic, I. M., Muzzio, M., Huang, Z., Thompson, T. N., McCormic, D. L. Pharmacokinetics, oral bioavailability, and metabolic profile of resveratrol and its dimethylether analog, pterostilbene, in rats. Cancer Chemother Pharmacol. 2011, 3(68), 593-601, doi: 10.1007/s00280-010-1525-4.

6. Acharya, J. D., Ghaskadbi, S. S. Protective effect of Pterostilbene against free radical mediated oxidative damage. BMC Complement Altern Med, 2013, 238(13), 110, doi: 10.1186/1472-6882-13-238.

7. Wenzhe, Yu., Xiaoqian, Hu., Mingfu, Wa. Pterostilbene inhibited advanced glycation end products (AGEs)-induced oxidative stress and inflammation by regulation of RAGE/MAPK/NF- $\mathrm{BB}$ in RAW264.7 cells. Journal of Functional Foods, 2018, (40), 272-279, doi: 10.1016/j.jff.2017.11.003.

8. Szkudelska, K., Szkudelski, T. Resveratrol, obesity and diabetes. European Journal of Pharmacology, 2010, (635), 1-8, doi: 10.1016/j.ejphar.2010.02.054. 
9. Wang, M., Jiang, S., Yu, F., Zhou, L., Wang, K. NonCoding RNAs as Molecular Targets of Resveratrol Underlying Its Anticancer Effects. Journal of Agricultural and Food Chemistry, 2019, 17(67), 4709-4719, doi: 10.1021/acs.jafc.9b01667.

10. Li, J., Zhang, C.-X., Liu, Y.-M., Chen, K.-L., Chen, G. A comparative study of anti-aging properties and mechanism: resveratrol and caloric restriction. Oncotarget, 2017, 39(8), doi: 10.18632/oncotarget.20084.

11. Perlmutter, D., Loberg, K. Yeda i mozg. Chto uglevody delayut so zdorov'yem, myshleniyem i pamyat'yu: Nauchnaya literatura. New-York, 2013, 460.
12. Polyvanov Y., Kogan A. Evaluation of the relevance of the development of food modules with pterostilben and resveratrol of natural origin. Dynamics of the development of world science. Abstracts of the 1st International scientific and practical conference. Perfect Publishing. Vancouver, Canada, 2019, 248-250.

13. Polyvanov, Y., Kogan, A. Berry powders with a high content of pterostilbene and resveratrol in the technology of chocolate flour confectionery. Scientific discoveries: projects, strategies and development: Collection of scientific papers $" \Lambda{ }^{\prime} О Г О \Sigma$ » with Proceedings of the International Scientific and Practical Conference, Edinburgh, 2019, (1), 68-70.

\section{Сведения об авторах (About authors)}

Alisa Kogan - student, Oles Honchar Dnipro National University, Dnipro, Ukraine; ORCID: 0000-0002-5863-8686; e-mail: alisakogan2000@gmail.com.

Коган Аліса Борисівна - студентка, Дніпровський національний університет імені Олеся Гончара, м. Дніпро, Україна; ORCID: 0000-0002-5863-8686; e-mail: alisakogan2000@gmail.com.

Yehor Polyvanov - student, Oles Honchar Dnipro National University, Dnipro, Ukraine; ORCID: 0000-0003-4999-5187; email: mr.egor.pv@gmail.com.

Поливанов Сгор Андрійович- студент, Дніпровський національний університет імені Олеся Гончара, м. Дніпро, Україна; ORCID: 0000-0003-4999-5187; e-mail: mr.egor.pv@gmail.com.

Iryna Honcharenko - Assistant of the department: Food Technologies, Oles Honchar Dnipro National University, Dnipro, Ukraine; ORCID: 0000-0001-9349-254X; e-mail: goncharenkoira88@ukr.net

Гончаренко Ірина Петрівна - асистент кафедри харчових технологій, Дніпровський національний університет імені Олеся Гончара, м. Дніпро, Україна; ORCID: 0000-0001-9349-254X; e-mail: goncharenkoira88@ukr.net

Katerina Suprunenko - Assistant of the department: Food Technologies, Oles Honchar Dnipro National University, Dnipro, Ukraine; ORCID: 0000-0002-8741-5449; e-mail: suprunenko.katerina90@gmail.com.

Супруненко Катерина Свгенівна - асистент кафедри харчових технологій, Дніпровський національний університет імені Олеся Гончара, м. Дніпро, Україна; ORCID: 0000-0002-8741-5449; e-mail: suprunenko.katerina90@gmail.com.

Please cite this article as:

Kogan, A., Polyvanov, Y., Honcharenko, I., Suprunenko, E. Pterostilbene enrichment of dry convenience food for instant muffins. Bulletin of NTU "KhPI". Series: New solutions in modern technologies. - Kharkiv: NTU "KhPI", 2019, 2, 61-66, doi:10.20998/2413-4295.2019.02.09.

Будь ласка, посилайтесь на ицю статтю наступним чином:

Коган, А. Б. Збагачення птеростильбеном сухого напівфабрикату для мафінів швидкого приготування / А. Б. Коган, Є. А. Поливанов, І. П. Гончаренко, К. Є. Супруненко // Вісник НТУ «ХПI», Серія: Нові рімення в сучасних технологіях. Харків: НТУ «ХПІ». - 2019. - № 2. - С. 61-66. - doi:10.20998/2413-4295.2019.02.09.

Пожалуйста, ссылайтесь на эту статью следующим образом:

Коган, А. Б. Обогащение птеростильбеном сухого полуфабриката для маффинов быстрого приготовления / А. Б. Коган, Е. А. Поливанов, И. П. Гончаренко, Е. Е. Супруненко // Вестник НТУ "ХПИ», Серия: Новые решения в современных технологиях. - Харьков: НТУ «ХПИ». - 2019. - № 2. - С. 61-66. - doi:10.20998/2413-4295.2019.02.09.

АННотАЦИЯ: Современное общество перегружено неконтролируемыми потоками информации, эмоциями, стрессами. $B$ дополнение ко всему, несмотря на пропаганду здорового питания, население многих стран страдает избыточным весом, ожирением и диабетом 2 типа. Роль генов в развитии диабета, ожирения и старческого слабоумия не так уж и велика. У подавляющего большинства людей, значительными факторами возникновения синдромов являются пищевые привычки. Мучные кондитерские изделия, к которым относятся маффины, завоевали популярность во многих странах мира, следовательно разработка технологий, связанных с обогащением классических рецептур полезными веществами или компонентами, имеет актуальность и необходимость. Это также связано с расширением рынка мучных кондитерских изделий, отвечающих стратегии сбалансированного и оздоровительного питания. Целью статьи является разработка рецептур и технологии маффинов быстрого приготовления из сухого полуфабриката с добавлением сухого порошка голубики, как источника птеростильбена - вещества, что позволяет снизить риск преждевременного старения, болезни Альигеймера, диабета 2 типа, последствия стресса и депрессии. Предложенная технология обеспечивает сохранение полезного действия биологически активного вещества после термической обработки, поскольку предложено кратковременное воздействие подготовленной смеси в поле сверхвысоких частот. Разработанные сухие смеси для маффинов могут быть рекомендованы для широких слоев населения, поскольку не содержат жира и сахара. Сладость готовому изделию придает экстракт из листьев стевии. В составе маффинов не содержится химических разрыхлителей. Ключевые слова: мучные изделия; маффин; птеростельбен; порошок голубики; деменция; раннее старение; диабет 2 типа 